\title{
Analyzing the Effect of Information Technology System Application Product (SAP) on Public Sector Organization's Performance: (A Case Study of Accountant General Khyber Pakhtunkhwa Office Peshawar)
}

\author{
YASIR KHAN \\ Ph.D Scholar, Qurtuba University Peshawar \\ yasirok62@yahoo.com \\ DR. SAIMA BATOOL \\ Assistant Professor, Qurtuba University Peshawar \\ dr.saimabatool90@yahoo.com \\ DR. SHAHID JAN \\ Associate Professor, Abdul Wali Khan University, Mardan \\ shahidjan@awkum.edu.pk
}

\begin{abstract}
The advance Accounting software and information system are very vital in public sector. The globalization demands the change toward new technology. Computerized Accounting software like SAP really works in minimizing the work burden and brings efficiency in working profile. History shows that those organizations which focused on their technological improvement proved to be successful organizations on the planet. The study has focused on Public sector organization where most of the work was done manually rather than using the advanced computer infrastructure and information system. The study surveyed 150 employees of the Accountant General Office Khyber Pakhtunkhwa Peshawar of both junior and senior level. The study used stratified random sampling technique creating strata's for both junior and senior level employees. The selfadministered15 items questionnaire was used tested for validity and reliability. The results found that both type of employees have been benefited from the application and use of computer and information system.
\end{abstract}

Keywords: SAP Accounting Software, Information technology, information system, infrastructure and Organization Performance.

\section{Introduction}

In Pakistan, the system of financial management has been innovated significantly since long. This has helped the government to manage the financial affairs of the state in efficient manner and to create an environment which is more favorable from operational point of view for the public sector entities. The Government of Pakistan has taken initiatives for restructuring of the existing system of financial reporting and financial management with a view to improve the overall government accounting system 
through system application product (SAP R/3). The legacy system of accounting was not had the capacity to meet the requirements of budgeting however it gave information of financial statements and performance which was not fully assure able and reliable. In addition, in the previous framework of the growing national and international integration and requirements of public sector management reform, the Government of Pakistan accounting system needs to be improved by conversion towards computerized Accounting system which was only possible by adopting and to emerging into information technology SAP (salman, 2014). The emergence and advancement in Information Technology has caused dramatic revolution in all aspect of human endeavor. The information technology applications and technological elements have changed the demonisms and dynamics of businesses and organizations. The world shifted human being from industrial age to computer and information age (Digital age) and world become digital world in which every activities strictly done over Information Technology and different Information System are interlinking by communicational network internet and software. Internet and connectivity play the role of live oxygen though which the whole world is connected. IT applications and strong internetworking infrastructure has caused sources of opportunities in business and organizations. The technological advancement and computer modernization has made the transformation of information easy, speedy, and timely. Information Technology and Information System are based on applications and internetworking infrastructure that improved the efficiency functionality and flexibility of the organizations and business. Through Information Technology based strategy have perhaps even changed the business models of the organizations and has made them much diversified organizations. Computer applications have become the more indispensible vehicles of the vital development, improvement and have made the actualization of resources (Debela, 2009).

Information Technology has really affected the performance of blue color workers. Computer applications have made them more efficient workers than before. Computer technology is very vital for both public and private organization as it helps in org planning, controlling, directing, budgeting and reporting (Bhuiyan, 2011).The computerized Accounting applications and conversion of system form manual to computerization has key contribution and usefulness in the public sector organization performance. The work flow sharply increases resulting increase in general public welfare which is an important part of Government responsibilities. These have been witnessed in health, military, judiciary, business, education and other parts of the society. Computer technology has caused improvement in service delivery, operation execution, transformation and finishing of the products. Pakistan is a developing country in transition phases of computer technology and internetworking infrastructure. Most of the government organizations have adopted the application of computer, internet and web based information system in their operations and decision making process.

\subsection{Problem Statement}

Pakistan is a developing country in which most of the organizations process data through legacy system. Accountant General Office Peshawar is among the public sector organization which has adopted the SAP application. To know how much the organization has succeeded in covering the improper and poor means of information and 
processing. This research investigated the impact of computerized accounting SAP on the organization Performance.

\subsection{Objective of the Study}

The main objectives of conducting this research study are the following

- To investigate the impact of Computerized Accounting Software SAP, internet and information system on the performance of Accountant General Office.

- To find the contribution of SAP and information system in the organizing, planning, controlling, co-ordination, budgeting and reporting.

- To know the importance of the application, internetworking (internet) and web based information computerized system as compared to the legacy system (Traditional information system).

- To suggest measures on the bases of findings of this research.

\section{Literature Review}

The system application product is an advance level of application IT product used for Accounting Information System. SAP is the fourth largest company in the world providing SAP software for computerized Accounting. The SAP R/3 system is a business software package designed to integrate all area of a business. It provides end to end solutions for financials, manufacturing, logistics and distribution. All business Process are executed in one SAP system and sharing common information with everyone. Information Technology based strategy bring positive revolution in the performance of the organization such as business firms ,health care centers, traffic control system in area of critical operational management and decision making in complex situation for the operational managers and executive managers. The computerized Accounting enhance employees performance, standardization of services, strong collaboration various activities, strong and sustainable consumers relationship from the services and from employee of the organization and real time communication to consumers and organization achieved their goals effectively in shorter time by investing limited resources and limited financing. Through the implementation of Information Technology\& Information System based strategic planning the organization become intelligent and due to intelligence the administration and operation of organization will be effective so the organization become smart and smart organization achieved the their objectives successfully (Zambrano, 2008).

Different Information Technology techniques like data base management system for data management of the organization, data warehouse, data mining, cloud computing, virtualization, remote computing, data grading, mobile computing, crowd sourcing, GSM, GPS, ubiquitous computing techniques and information system centralized ,distributed and web based information system similarly the modern infrastructure s and architecture of Information Technology also play an important contribution in smart organization (Harthony, 2009). Debela (2009) argued that Information Technology automata have really affected the performance of blue color workers. He further added that Information Technology applications have made them more efficient workers than before. Computer technology is very vital for both public and private organization as it helps in organization planning, controlling, directing, budgeting and reporting. Information Technology implementation and Information System support and improves 
the delivery of services at very excellent pedestal due to high processing and better quality of management and the performance in both private and publics organization definitely increased the technology based strategy in the organization help in operations like transaction, controlling the transaction, other offices automation daily customers recording, employees attendance record, security concerned issue ,budgeting ,reporting and Information Technology\& Information System based strategy also support critical decision which are taken by the organization managers, operation managers and executive managers of in shorter me with accurate analysis design best decision making in complex situation ,Information System is the strategic engineering of Information Technology infrastructure and architecture disciplined to combine people, software technologies, hardware technologies, telecommunication network technology and data base technologies that accept data from external environment ,process data, stored the information/data and produces output reports to external environment for various sort decision maker of the organization.

Fountain (2007) suggest that government organization require to distribute the work of organization because work distribution bring great revolution in services and management and the administration will be effective by decomposing /splitting the structure of organization so performance will be improved this only possible by implement IT based strategic planning for administration and services distribution and the cost ,time and resources will be better managed. Zambran (2008) recommend that IT based strategy planning the services of the organization improved instead of manual information system in organization .He suggested that Information System is reliable and cost effective and computerized based system eliminate the problem redundancy of data in the organization, bring accuracy, sharing of information in the organization and their consumers, reliable backup facilities, up gradation and maintenance facilities, integration and integrity ,free infrastructure data advisability, security and privacy so all these are Information Technology based planning through which the performance of the organization. Aribisala (2008) asserted that Information Technology infrastructure is absolutely important for better and effectively managing and coordinating the public sector organizations. In health center the patient monitoring effectively computerized based system is important and similarly when army deployed in battle filed the proper coordination is necessary for real time operation so without Information Technology based techniques it obviously difficult in this age of technology , similarly industrial processing system the different activities monitoring at real time is important like product designing industries temperature and cooling condition detection is so critical important and Information Technology based strategy is necessary for communication in organization because traditional communication are costly and Information Technology based calling system are reliable for communication.

Harthony (1990) stated that heterogeneous infrastructure and different architecture are available for communication of text, audio, video, image, voice data and now web based system carry strong GPRS in reliable manners different companies manufactured and designing the communication network equipment like hub, switch, router, terminal devices like laptop, desktop, mobile devices and wireless and wire media and speed of internet bring effective communication infrastructure and communication 
become chippers and reliable. Olorunsola and Ekong (2006) stressed that e mail is reliable and cost effective and secure method of data transferred in the organization this also a great contribution of Information Technology in organization. Ajayi and Ayodele (2002) stated that Information Technology bring excellent changed in GDP of country and the economy become emerging economy so puts vital importance in economy development. According to Bhuiyan (2011) the web based computerized information system the for business firm assist the business and all the business activities are linked to web so the business become e business and e business all the activities are strictly done over the web so it also called web based business all supported activities or subcategories like e marketing commerce, e-banking mailing shopping purchasing, e trade, e knowledge learning, e-ordering all activities defiantly support business. If Information Technology based strategic planning are deployed for business today then business can achieved the objectives in shorter time with limited resources. Information Technology based business has various benefits for the firm and consumers e-business, customer satisfaction is high and strong and sustainable relation build with customer, Information Technology based business will be globalized because internet based marketing worldwide customer are created so customers purchased ratio to sale will be high and ultimately business firm getting high revenues which is main goal of every business firm in shorter interval of time, price reduction ,standardization of services, customers feedback, competitive advantage, 24 hours engagement of customers, and free services and employee services performance is vision of Information Technology based tactic of business.

\subsection{Research Hypotheses:}

$\boldsymbol{H}_{0}$ : There is no impact of computer and internet working on the efficiency of AG Office Peshawar.

$\boldsymbol{H}_{1}$ : There is positive impact of computer and internet working system on the efficiency of $A G$ Office Peshawar.

$\boldsymbol{H}_{0}$ : There is no significant difference between the efficiency of junior and senior level employees due to computer and information system.

$\boldsymbol{H}_{2}$ : There is significant difference in efficiency of junior and senior level employee due to computer and information system.

Corporate Governance Factors

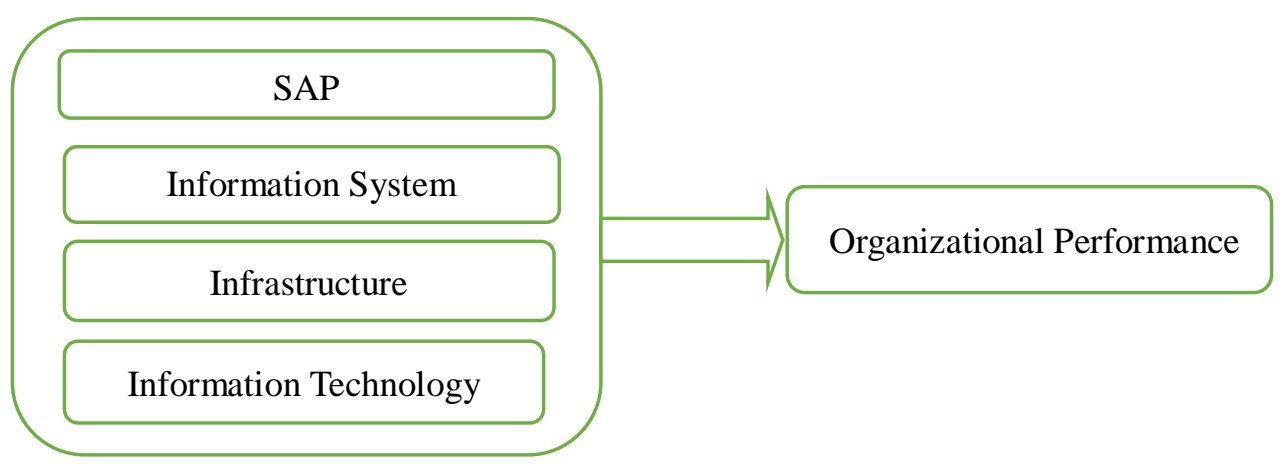

Figure 1: Theoritical Framework 


\section{Methodology}

This is a descriptive research. The data of this research was collected from 150 employees of Accountant General Office Peshawar. These employees were segregated in different strata's. The employees were distributed in junior and senior levels. So the stratified random sampling technique was adopted in this research study. The questionnaire of this research was comprised of 15 items. The research questionnaires was self-administrated, the questionnaire was validated and cheeked for reliability. T- test has been applied to conclude the results.

\section{Data Analysis}

The below tables show the results of the impact of Computer Accounting and information system on the AG Office Performance. In the below table 1 represent junior level employee and 2 represent senior level employees. The results suggest that there is no difference in the efficiency of junior level employees and senior level employees. The levene's test suggest that the impact of computer and information system has an impact on the efficiency of the civil secretariat employees and there is no difference in the efficiency of both junior and senior level employees. As the Levenes, test value is insignificant at 5\% probability. Both employees level showing similar responses to computer and information system on the employee's efficiency. So all classes of employees are benefited from the use of computer application and information system.

Table 4.1: Groups Statistics

\begin{tabular}{lcccrr|}
\hline & employees & $\mathrm{N}$ & Mean & Std. Deviation & Std. Error Mean \\
Computer and & 1.00 & 120 & 3.8319 & .13564 & .01086 \\
information & 2.00 & 30 & 3.7302 & .17730 & .02997 \\
system & & & & & \\
\hline
\end{tabular}

Table 4.2: Independent Samples T-Test

\begin{tabular}{|c|c|c|c|c|c|c|c|c|c|c|}
\hline & & \multicolumn{2}{|c|}{$\begin{array}{l}\text { Levene's } \\
\text { Test for } \\
\text { Equality of } \\
\text { Variances }\end{array}$} & \multicolumn{7}{|c|}{ t-test for Equality of Means } \\
\hline & & \multirow[t]{2}{*}{$\mathrm{F}$} & \multirow[t]{2}{*}{ Sig. } & \multirow[t]{2}{*}{$\mathrm{t}$} & \multirow[t]{2}{*}{$\mathrm{df}$} & \multirow[t]{2}{*}{$\begin{array}{c}\text { Sig. } \\
\text { (2-tailed) }\end{array}$} & \multirow[t]{2}{*}{$\begin{array}{c}\text { Mean } \\
\text { Difference }\end{array}$} & \multirow[t]{2}{*}{$\begin{array}{l}\text { Std. Error } \\
\text { Difference }\end{array}$} & \multicolumn{2}{|c|}{$\begin{array}{l}95 \% \text { Confidence } \\
\text { Interval of the } \\
\text { Difference }\end{array}$} \\
\hline & & & & & & & & & Lower & Upper \\
\hline \multirow[t]{2}{*}{$\begin{array}{l}\text { Computer } \\
\text { and } \\
\text { informatio } \\
\text { n system }\end{array}$} & $\begin{array}{l}\text { Equal } \\
\text { variances } \\
\text { assumed }\end{array}$ & 2.76 & 0.1 & 3.78 & 189 & 0 & 0.102 & 0.027 & 0.049 & 0.155 \\
\hline & $\begin{array}{l}\text { Equal } \\
\text { variances } \\
\text { not } \\
\text { assumed }\end{array}$ & & & 3.19 & 43.35 & 0.003 & 0.102 & 0.032 & 0.037 & 0.166 \\
\hline
\end{tabular}




\section{Conclusion}

The Information Technology (IT) and IS(information system) based strategy bring positive revolution in the performance of the organization such are business firms ,health care centers, battle field management, traffic control system in area of critical operational management and decision making in complex situation for the operational managers and executive managers. The IT \& IS strategic planning having greater opportunities such are improved employees performance ,standardization of services, strong collaboration various activities, strong and sustainable consumers relationship from the services and from employee of the organization and real time communication to consumers and organization achieved their goals effectively in shorter time by investing limited resources and limited financing. This research was aimed at knowing the effect of Information Technology SAP (System Application Product) on Public sector Organization performance. The research was conducted using self-administered questionnaire analyzing 150 junior and senior level employees for the purpose. The results revealed that computer and information system has positive impact on the employees of efficiency in this particular organization employees. The results suggest that computer has same impact on both level employees.

\section{References}

Ajayi, I. A. \& Ayodele, J. B. (2002). Fundamentals of Educational Management. AdoEkiti:Greenline Publisher.

Argyres, N. S. (1999). The Impact of Information Technology on Communication: Evidence from the B-2' Stealth Bamber, Organization Science 10(2), 162-180.

Aribisala, J. O. (2008). Technology in Globalization in Bandele, Olorunsola, Okunade\&Ibijola (eds) in Information and Communication Technology and Computer Applications. Ado-Ekiti; Generalstudies Unit, University of Ado-Ekiti.

Ayeni, J. O. A. (1992). Fundamental of Computing Lagos: Unilag Press.

Bhuiyan, M. S. H. (2011). Public Sector eService Development in Bangladesh Status Prospects and Challenges. Electronic Journal of e Government 9(1), 15-29.

Debela, T. (2009). The Role of Information Technology in Enhancing the Administrative Capacity of the Civil Service USA: Lesson from the USA.

Fountain, J. E. (2007). Better Public Service for Growth and Jebs. National Center for DigitalGovernment (NCDG), USA. NCDG Occasional paper No 07-007 (Online) Availablehttp://scholarworks Umassedu/cgi?anticles $=1025 \&$ context=ncclg $\quad 10$ March 2010,

Harthony, M. G. (2009). Mini and Macro Computer Systems, London; ELBS // Macmillian

Harderson, J. C \& Venkatraman, N. (1994). Strategic Ailonmenti a Model for Organizational Transformation via Information Technology. In Allen, T.J. and Mortons, S. (Eds). Information Technology and the Corporation of the 1990. New York: Oxford University Press.

Muhammed, R. B. Abdulkarim, (1995). Improving the Efficiency of the Public sector www://unp

Nerisa, K. \& Millicent, O. (2007). Impact of e Government on Management and use Government Information in Kenya 
Pickering, J. M. \& King, J. L. (1996). Hardwiring weak ties: Inter-organizational Computer Mediated Communication. Occupational Communities and Organizational change Organisation service, 6(4);479-486.

Zambrano, R. (2008). E-Government and Development Service Delivery to Empower the Poor International Journal of Electronic Government Research 4(2) 1-13 